\title{
CHARACTERISTICS OF SOILS AND THE SOIL COVER IN THE KOSTOMUKSHA STATE NATURE RESERVE, RUSSIA
}

\author{
Olga N. Bakhmet ${ }^{1, *}$, Maria V. Medvedeva ${ }^{2}(\mathbb{D}$, \\ Boris V. Raevsky ${ }^{\circledR}$, Sergey G. Novikov² ${ }^{(D}$, Tatyana S. Shelekhova ${ }^{3}(\mathbb{D}$ \\ ${ }^{1}$ Department for Multidisciplinary Scientific Research of the Karelian Research Center of RAS, Russia \\ *e-mail: obahmet@mail.ru \\ ${ }^{2}$ Forest Research Institute of the Karelian Research Center of RAS, Russia \\ ${ }^{3}$ Institute of Geology of the Karelian Research Center of RAS, Russia
}

Received: 22.04.2020. Revised: 10.09.2020. Accepted: 22.10.2020.

\begin{abstract}
Studies were carried out in the Kostomuksha State Nature Reserve, situated in the northern taiga of East Fennoscandia. We have described the main stages of research on the soils and soil cover in the study area. The analysis of the soils and soil cover of this Protected Area was integrated with the study of the parent rock material and woody vegetation. Soils of intact areas serve as an etalon during the monitoring of forest ecosystems disturbed anthropogenically. This makes our study to be of high relevance. This study was aimed to investigate the composition of the soil fund, and properties of most widespread soils in the Protected Area. The morphological and physicochemical properties of the soils were studied. Natural conditions of the Kostomuksha State Nature Reserve are favourable for the podzolisation process. The most widespread in the Protected Area are zonal Al-Fehumus soils (Podzols). Shallow soils (Leptosols) are formed on bedrock outcrops. They have a minor proportion of the entire soil amount. The productivity of plants growing on them is low. Wet sites are occupied by intrazonal peat moor soils (Histosols), by covering small areas. They are developed in the lowlands, between hills, in mire margins, in saucer-like concavities on bedrock outcrops. The names of the studied soils were determined according to the both regional soil classification and WRB classification. The soil association with the tree stand composition was identified. Albic Rustic Podzols predominate under pine (Pinus sylvestris) stands, while spruce (Picea abies) stands are far less widespread. Birch (Betula pendula) stands on soils of podzolic genesis occupy limited areas and occur on clear-cuts, sites affected by windfalls and wildfires. The associations between soils and quaternary deposits were analysed. Bedrocks overlap with sandy and loamy sand quaternary deposits, the thickness of which ranges from $5 \mathrm{~cm}$ to $5 \mathrm{~m}$. Morainic and glaciolacustrine sediments are the most widespread. Peat deposits are less common in the study area. Morphologically, the soils are usually characterised by a welldifferentiated profile, a thick forest floor $(\mathrm{O})$, and an ongoing podzolisation process. The soils are mostly coarsetextured. The low content of the fine powder fractions indicates that the weathering of primary minerals inside the soil is minor due to the cold and humid climate. No clear relationships were observed in their distribution across the soil profile. The studied soils are acidic. The acidity is the highest in the forest floor and it declines with an increasing depth of the soil profile. The formation of the soil organic matter is influenced by specifics of the primary soil-forming factors. The soils contain a high carbon (C) amount in the top organic horizon, with a sharp decline in its content with depth. The nitrogen $(\mathrm{N})$ distribution along the soil profile correlates with the overall organic matter distribution. So, it is the highest in the forest floor, while it declines towards the mineral soil layer. In the forest floor, the broad $\mathrm{C} / \mathrm{N}$ ratio is an indirect evidence of a slow microbial transformation of organic matter in the studied soils. The small amount of most macroelements and microelements in soils of the studied Protected Area is quite low. In general, this is typical for soils in the Republic of Karelia. The exceptions are $\mathrm{Fe}, \mathrm{Cu}$, and $\mathrm{Zn}$, since the study area is associated with iron-ore deposits. In the study area, the soil cover is highly motley due to a high diversity of parent rock material and relief features. Considering the coarse texture, low humus content and a well-drained hydrology of the soils, elements can be leached out of the root layer. The obtained data can serve as the background for environmental monitoring. They can be accurately extrapolated to soils of other intact forest ecosystems of Fennoscandia.
\end{abstract}

Key words: Eastern Fennoscandia, forest ecosystems, forest soils, Quaternary deposits, soil valuation

\section{Introduction}

Protected Areas (PAs) constitute a national wealth. Their role is crucial for conserving natural landscapes, complexes, and biodiversity, in maintaining the ecological balance in physiographical zones. PAs adjacent to Russian borderlands are of huge international significance
(Deguignet et al., 2014; Melillo et al., 2016; UNEP-WCMC and IUCN, 2016). PAs comprise lands of special value in terms of nature conservation, historical, cultural, recreational, and other perspectives. Their importance for nature conservation is being highlighted in many publications around the world (e.g. Arnalds et al., 1995; Lu 
\& Zhang, 2008; Getzner et al., 2014; Rodríguez et al., 2014; Lordkipanidze et al., 2015; Kulmatiski et al., 2017). Being a vital component of the natural environment, soils are a subject to protection as much as plants and animals, surface and subsurface waters or air (Aparin et al., 2007; Van Wensem et al., 2008).

The industrial impact on the environment has been growing constantly. No many areas retained its original state (Dazzi \& Lo Papa, 2015). This issue is relevant in Northwest Russia, too. In this region, human pressure on the natural environment has been intensifying, since substantial forest areas get clear-cut, the air, water, water catchments, and soils get increasingly contaminated (Dobrovolskiy, 1997; Gromtsev, 2020). The industrial anthropogenic pressure is expected to gain momentum, aggravating the environmental situation (approved by Order of the Ministry of Industry and Trade of Russia dated 05.05.2014, №839).

In the Republic of Karelia, 144 Protected Areas of various categories have been substantiated and founded, namely state nature reserves, national parks, landscape sanctuaries, natural monuments, areas of historical-cultural value (Gromtsev, 2020). One of the PAs is the Kostomuksha State Nature Reserve (SNR).

In the study area, the first soil research dealt with soil mapping in the Republic of Karelia to portray the differentiation of the soil cover into zones and regions (Mikhailovskaya, 1951). This large-scale map was prepared on the basis of fragmentary fieldwork efforts, and using data on climatic, lithological-geographical and geological characteristics in the study area. Then, this obtained map became the main one for conducting the soil-ecological studies in this region (Morozova, 1996).

The discovery and mining of the iron-ore deposits were the key reasons for a further thorough research in the study area and investigation of its ecological characteristics, including intensive research of soils and the soil cover (Erukov et al., 1977). The foundation of the Kostomuksha SNR in 1983 was crucial for initiating the soil studies in this region. Once the Kostomuksha Ore Mining and Processing Mill (GOK) was launched in 1982, research on the effects of air-borne pollution on forest ecosystems was mobilised. In this period, Finnish colleagues also actively studied and analysed the ecological status of the industrial hub. They conducted its comparisons with the background parameters, including from the Kostomuksha SNR, and numerous other multidisciplinary studies (Poikolainen, 1995). During this period, there was an accumulation of information about heavy metals in soils, changes in acidityalkalinity parameters, structural and functional organisation of the soil microbial community, natural variations in the soil enzymatic activity (Medvedeva \& Bakhmet, 2001; Medvedeva et al., 2003, 2006a,b). Soils of the Protected Area were used as an etalon in the research on soil remediation in disturbed ecosystems around the industrial hub (Medvedeva \& Yakovlev, 2011; Fedorets et al., 2015).

In 1992, in the Kostomuksha SNR was established the polygon Kamalahti, an International Cooperative Programme on Integrated Monitoring of Air Pollution Effects on Ecosystems (ICP/ IM). It was the only such site in the Republic of Karelia. This site is operated using GIS-incorporating thematic maps of the forest cover, habitats, basement rocks and Quaternary deposits, as well as the results of the measurements of different environmental parameters at sampling points (Martinelli \& Pignatelli, 1995; Kolomytsev \& Shiltsova, 1998; Van Herk et al., 2003).

ICP Forests programme substantially contributed to creating the database on the state of the natural environment, harmonisation of Russian and international soil research methodology and, in general, integration of the knowledge about forest ecosystems (Hiederer et al., 2011). This programme was the framework for soil studies in 2009-2010, including surveys in the Kostomuksha SNR.

In the latest decade, soil research in the Kostomuksha SNR was associated with the organisation of the forest monitoring network. This implies an integrated approach to the study of forest communities, taking into account forest management data, including versatile information on the structure of the forest fund land, as well as analysis of mass statistics data from forest inventories (Raevsky, 2016).

As new data on soils of the Kostomuksha SNR were accumulating during many years, their synthesis and summarisation are of high importance. This paper reports the results of the longterm complex studies of soils and the soil cover in the Kostomuksha SNR. These data could be used in environmental monitoring, and accurate extrapolation to soils across Fennoscandia. 


\section{Material and Methods}

Kostomuksha SNR is situated in the northern taiga subzone in the Republic of Karelia $\left(64.5833^{\circ}-64.3166^{\circ} \mathrm{N}, 30.6166^{\circ}-30.0333^{\circ} \mathrm{E}\right)$. According to the landscape zonation, the Kostomuksha SNR belongs to the hilly and hillyridge (with a complex of glacial landforms), tectonic-denudation, moderately paludified type of landscape (Gromtsev, 2000).

The Protected Area is situated in the centre of the West-Karelian Upland, which spurs from the Maanselka watershed ridge (Peikhvasser, 1989; Erokhin \& Moskvitin, 2001). The altitude varies from $100 \mathrm{~m}$ a.s.1. to $300 \mathrm{~m}$ a.s.1., indicating heavily dissected terrain. The study area includes a variety of landforms. Of them are large ridges and isometric hills of tectonic denudation genesis, tops of which are the crystalline basement, common in the north. The western parts of the landforms are represented by structural-denudation plains. A subhorizontal denudation plain lies in south-east of the study area. The plain surface is levelled off by a blanket of moraine of varying thickness. Large orographic landforms are clearly trending north-west to south-east.

According to the agroclimatic zonation, the study area belongs to the northern lake district. The area has a temperate climate, with a short growing season (frost-free period lasts 85-95 days), low air temperatures (number of days with air temperatures above $10^{\circ} \mathrm{C}$ is $85-90$ ), and a high amount of precipitation (550-600 $\mathrm{mm}$ per year). The climate in the area is considerably influenced by Lake Kamennoye, which smooths down winter and summer temperature variation, and forms a peculiar hydrological network (average annual runoff is up to $350 \mathrm{~mm}$ ).

The dominate type of plant communities is pine (Pinus sylvestris L.) forests with variation from rocky pine forests to Carex-Sphagnum pine forests, where Vaccinium vitis-idaea pine forests are dominated. This is caused by topographic and soil cover characteristics, coarse texture of the parent rock materials, as well as frequent wildfires. Spruce (Picea abies (L.) H.Karst.) stands are distributed evenly across the study area, and are localised in depressions between ridges and hills. The ground cover in the Protected Area is variable, with northern boreal elements dominating. The highly heterogeneous lithogenic composition of large- and medium-size orographic features is responsible for the high mosaicity of the ground cover. The forest productivity is low. The average forest stand quality class is $\mathrm{V}$. Recovery of the forest stands after natural and technogenic disturbances is rapid. In the early post-fire succession series, the forest stands grow actively and are characterised by a high stocking rate.

The integrated approach to study soils and the soil cover incorporates research into the structure of the forest cover and Quaternary deposits, which determine the specifics of the soil-forming process. Based on the past extensive surveys of the soil cover in the Kostomuksha SNR, we identified the most typical soils formed under the widespread spruce stands. These soils were chosen as the objects for this study.

Surveys were carried out in five sample plots established in pine and spruce forests. Soil pits were made in each sample plot. Additional shallow by-pits were dug for a more detailed examination of the soil cover (Field determinant of Russian soils, 2008). They were classified according to the Russian soil classification (Shishov et al., 2004). Comparisons with soil names accepted in both the regional classification (Morozova, 1991) and WRB classification (IUSS Working Group WRB, 2015) are provided (Table 1).

Table 1. Correlations between some classification systems for soils in the Kostomuksha State Nature Reserve

\begin{tabular}{|c|c|c|}
\hline Regional soil classification (Morozova, 1991) & Russian soil classification (Shishov et al., 2004) & WRB classification (IUSS Working Group WRB, 2015) \\
\hline Illuvial-Ferro-Humic Podzol & Illuvial-Humic Podzol & Albic Carbic Podzol \\
\hline Illuvial-Humo-Ferric Podzol & Illuvial-Ferric Podzol & Albic Rustic Podzol \\
\hline Raised bog peat soil & Oligotrophic peat soil & Fibric Histosols Dystric \\
\hline Poor-fen peat soil & $=$ & Fibric Histosols Eutric \\
\hline Illuvial-Humic peaty and peat Podzols & Gley Podzols, Gley Peat-Podzols & Dystric Histic Gleysols \\
\hline Peat-gley soil & Peat-Gleyzem & Dystric Folic Lithic Leptosol \\
\hline Primitive organogenic soil & Typic Petrozem & Dystric Folic Leptosol \\
\hline Primitive organogenic podzolised soil & Podzolised Petrozem & \\
\hline
\end{tabular}


Soil samples were taken with a division into genetic soil horizons, where the soil texture was determined using the method suggested by Kaczynsky, the $\mathrm{pH}$ values using potentiometrical method, total carbon and total nitrogen content using a $\mathrm{CHN}$ analyser, hydrolytic acidity and the sum of bases using the methods designed by Kappen (Vorobyeva, 1998). The total contents of macroelements $(\mathrm{Ca}, \mathrm{Mg}$, $\mathrm{P}, \mathrm{K})$ and microelements $(\mathrm{Pb}, \mathrm{Cu}, \mathrm{Zn}, \mathrm{Cr}, \mathrm{Fe})$ was determined using methods of atomic absorption spectrometry (AA-7000 spectrophotometer, Shimadzu, Japan). The total sulphur amount was determined spectrophotometrically (SF-2000, Russia). The data were obtained using the equipment of the Core Facility Analytical Laboratory of the Forest Research Institute, KarRC of RAS.

Soils of the Republic of Karelia were grouped and placed according to the valuation scales for various forest types. In this regard, we provided an integral quantifier for soil groups formed under various forest stands. Soils were scored on a 100 -score scale and combined into five groups on the basis of the genetic classification and systematisation list, with diagnostic characteristics and forest site qualities (Fedorets et al., 2000).

The data were processed by statistical analysis techniques (Dmitriev, 1995). For this purpose, we used Microsoft Office Excel 2007 tools.

\section{Results and Discussion}

The soil cover has a motley structure due to the complex relief and a high variation of the parent rock material. Soils belonging to different soil types have been formed in the studied Protected Area, which of them the most widespread are Podzols (Fig. 1).

Surveys demonstrated that the plant cover is not highly diverse. A majority of the study area is occupied by pine forests, while spruce stands have a smaller coverage (Table 2). Deciduous communities, i.e. birch (Betula pendula Roth) forests, cover less than $1 \%$ of the total area.

Our results show that the above mentioned forests are associated with all soil types, but their edaphic preferences are different. The most widespread types are Al-Fe-humus soils (Illuvial-Ferric and Illuvial-Humic Podzols), which account for up to $80 \%$ of the soil cover in the Kostomuksha SNR (Fig. 1, Table 2). The pine forests cover $80 \%$ of the area represented by soils of this type, while spruce forests occupy about $19 \%$ of this area and $1 \%$ of the area is occupied by birch forests. Table 2 shows forests associated with soils of the semihydromorphic and hydromorphic series, with contribution of no more than $20 \%$. Among them, pine forests on peat soils occupy $75 \%$ of the area, spruce forests $23 \%$, and birch forests $0.5 \%$. Disturbed ecosystems occupy $1 \%$. The proportion of pine and spruce forests growing on primitive soils does not exceed $3 \%$.

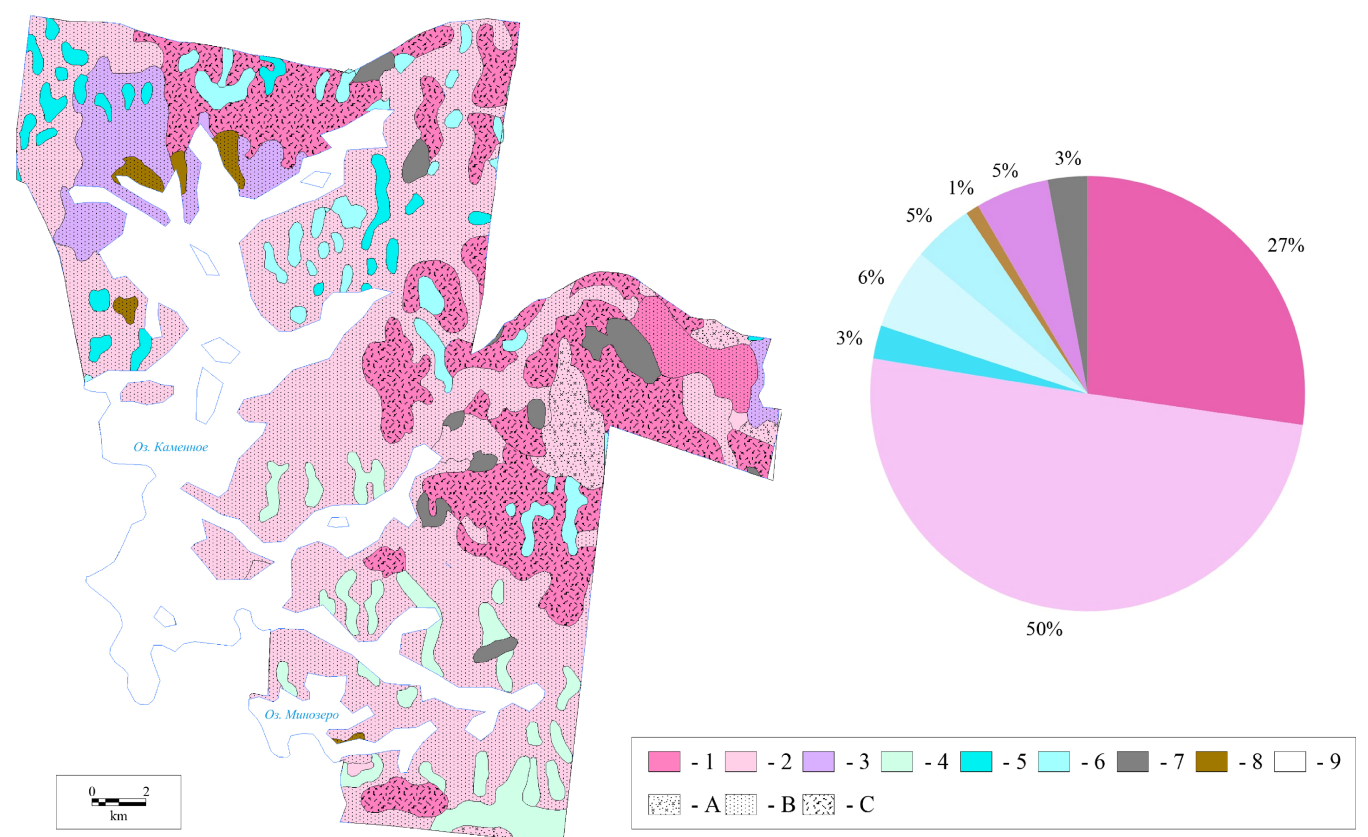

Fig. 1. The soil cover and structure of the soil fund of the Kostomuksha State Nature Reserve (The legend follows Shishov et al. (2004)). Designations: Soils: 1 - Illuvial-Ferric Podzols (Albic Rustic Podzols); 2 - Illuvial-Humic Podzols (Albic Carbic Podzols); 3 - Illuvial-Humic peaty and peat Podzols (Gleyic Histic Podzols); 4 - undefined wetland soils (Histosols); 5 - raised-bog peat soils (Fibric Histosols Dystric); 6 - poor-fen peat soils (Fibric Histosols Eutric); 7 - primitive soils on bedrock outcrops (Leptosols); 8 - anthropogenically altered podzolic soils (Anthrosols); 9 - uncertain soils of islands. Grainsize distribution: A - sandy-silty, bouldery, over till; B - sandy, sometimes with clay; C - silty loamy-sandy, bouldery, over till. 
Table 2. Distribution of the forested area in the Kostomuksha State Nature Reserve on the basis of the soil cover structure

\begin{tabular}{|c|c|c|c|}
\hline \multirow{2}{*}{ Soil name } & \multicolumn{3}{|c|}{ Stand area, $\mathrm{km}^{2}$} \\
\hline & Spruce forests & Pine forests & Birch forests \\
\hline Illuvial-Ferric Podzols & 15.11 & 54.59 & 0.23 \\
\hline Illuvial-Humic Podzols & 25.22 & 102.84 & 0.69 \\
\hline Raised-bog peat soils & 1.81 & 4.46 & 0.07 \\
\hline Undefined wetland soils & 2.48 & 12.89 & 0.03 \\
\hline Poor-fen peat soils & 3.60 & 7.90 & 0.05 \\
\hline Anthropogenically altered podzolic soils & 3.00 & 2.48 & 0.05 \\
\hline Illuvial-Humic peaty and peat Podzols & 1.91 & 11.79 & 0.28 \\
\hline Primitive soils on bedrock outcrops and immature/shallow Podzols & 1.67 & 5.89 & - \\
\hline Total & 54.80 & 202.84 & 1.40 \\
\hline
\end{tabular}

The valuation scores of the soils in the Kostomuksha SNR ranged from 0 to 70 . This indicates highly variable conditions for the development of the forest communities (Table 3 ).

The value of the most common soils has scores of 35-70, indicating an average fertility level of automorphic soils. Soils of hydromorphic genesis have lower (within 15-20) scores. Low-productivity soils ( $0-5$ scores) are formed on bedrock outcrops. Analysis of the productivity of the forest stands growing under similar edaphic conditions demonstrated that spruce forests are on average $10 \%$ more productive than pine forests. This is caused by the fact that in an intact ecosystem, spruce forests would replace pine forests, under the most favourable edaphic conditions.

One of the key soil-forming factors is the parent rock material, distribution patterns of which define the soil cover motleyness (Table 4). The main type of Quaternary sediments in the Kostomuksha SNR is direct glacial sediments, represented by sandy, often bouldery, till deposited after the Late Weichselian (Ostashkovian) glaciation at the Kalevala stage of deglaciation. Such glacial deposits are generally quite common also in the rest of Fennoscandia (Ylli-Halla \& Mokma, 2002). In most of the Kostomuksha SNR area, bedrock is covered up with an intermittent shallow (1-3 m) moraine sheath. In the southern part of the Protected Area, it is usually composed of a loamy sand till with a substantial admixture of fine-grained particles. Surveys demonstrated that the soils usually formed on direct glacial sediments are Illuvial-Ferric and Illuvial-Humic Podzols. In the study area, soil formation is constrained by the available thickness of loose sediments underlain by crystalline bedrock.

Glaciolacustrine sediments are represented by sand with gravel and cobbles, loamy sand, and loam up to $10-20 \mathrm{~m}$ thick. They form a narrow strip along Lake Kamennoye up to an altitude of $200 \mathrm{~m}$ a.s.1., and along smaller lakes. Also, they are known along the River Kamennaya valley, which was formed as an ancient glacial spillway. Quaternary sediments in the river valley formed in a heterogeneous manner. Thus, sediments in the upper course are of erosional genesis and composed of bouldery-gravelly alluvium, while in the lower course they are of accumulative genesis and sandy composition. A fluvioglacial delta is found at the river mouth. A series of terraces in the river lower course indicates a gradual decline in the water level of Lake Luvozero, from $163 \mathrm{~m}$ a.s.1. in the Early Holocene to $148 \mathrm{~m}$ a.s.l. today (Elina et al., 2005). Glaciolacustrine sediments have been formed in the paludal north-western part of the Kostomuksha SNR, where they are found on slopes between uplifted basement blocks overlain by moraine and in depressions between them, which are filled with biogenic peat-bog deposits. The soil cover formed over glaciolacustrine sediments comprises soils of different geneses: from automorphic (Illuvial-Ferric Podzols) to hydromorphic (raisedbog peat soils). Where loamy sand moraine comes in contact with biogenic peat-bog deposits, there would be an increased thickness of horizons, wedging of a horizon into another, increased biological activity of the soils, a more complex soil cover spectrum. 
Table 3. Soil valuation scores and average stock of the forest stands in the Kostomuksha State Nature Reserve

\begin{tabular}{|c|c|c|c|c|}
\hline \multirow{2}{*}{ Soils } & \multicolumn{3}{|c|}{ Average standing stock, $\mathrm{m}^{3} / \mathrm{ha}$} & \multirow{2}{*}{ Soil score } \\
\hline & Spruce forests & Pine forests & Birch forests & \\
\hline Illuvial-Ferric Podzols & 201 & 188 & 194 & $35-70$ \\
\hline Illuvial-Humic Podzols & 202 & 188 & 104 & $40-60$ \\
\hline Raised-bog peat soils & 202 & 172 & 104 & $15-20$ \\
\hline Poor-fen peat soils & 195 & 182 & - & $15-20$ \\
\hline Illuvial-Humic peaty and peat Podzols & 195 & 187 & 117 & $20-35$ \\
\hline Primitive soils on bedrock outcrops and immature/shallow Podzols & 211 & 180 & - & $0-5$ \\
\hline Mean & 201 & 183 & 130 & \\
\hline
\end{tabular}

Table 4. Soil types and affiliations with the genetic types of Quaternary sediments in the study area

\begin{tabular}{|c|c|c|c|}
\hline Soil & Soil texture & Type of Quaternary sediment & Landform \\
\hline $\begin{array}{l}\text { Illuvial-Humic and Illuvial-Ferric } \\
\text { Podzols }\end{array}$ & Sandy, sometimes with clay & $\begin{array}{l}\text { Direct glacial sediments (sandy } \\
\text { till with boulders) }\end{array}$ & Small hills, slopes of uplands \\
\hline Illuvial-Ferric Podzols & Silty loamy sand, bouldery & loamy-sand till & Gentle hill slopes, ridge tops \\
\hline $\begin{array}{l}\text { Illuvial-Humic peaty and peat } \\
\text { Podzols }\end{array}$ & Sandy, sometimes with clay & \multirow{3}{*}{$\begin{array}{l}\text { Glaciolacustrine sediments (sand } \\
\text { with gravel and cobbles, loamy } \\
\text { sand, loam) }\end{array}$} & $\begin{array}{l}\text { Shore areas of large and small } \\
\text { lakes, River Kamenka valley }\end{array}$ \\
\hline $\begin{array}{l}\text { Raised-bog peat, and poor-fen peat } \\
\text { soils }\end{array}$ & - & & $\begin{array}{l}\text { Poorly drained areas, flat plains, } \\
\text { shallow depressions }\end{array}$ \\
\hline $\begin{array}{l}\text { Illuvial-Humic and Illuvial-Ferric } \\
\text { Podzols }\end{array}$ & $\begin{array}{l}\text { Silty loamy sand, sandy, sometimes } \\
\text { with clay }\end{array}$ & & Hill slopes \\
\hline $\begin{array}{l}\text { Primitive organogenic soils, shallow } \\
\text { Illuvial-Ferric Podzols }\end{array}$ & $\begin{array}{l}\text { From silty loamy sand to } \\
\text { coarse sand }\end{array}$ & $\begin{array}{l}\text { Fluvioglacial deposits (sand with } \\
\text { gravel, cobbles and boulders, } \\
\text { well-graded, washed) }\end{array}$ & Esk \\
\hline All types of wetland soils & - & Biogenic peat-bog deposits & $\begin{array}{l}\text { Flat plains, crystalline basement } \\
\text { depressions }\end{array}$ \\
\hline $\begin{array}{l}\text { Shallow }\left(\begin{array}{lll}20 & \mathrm{~cm}\end{array}\right) \text { stony primitive } \\
\text { soils; fragmental Podzols }\end{array}$ & $\begin{array}{l}\text { Coarse- and medium sand, } \\
\text { eluviation-deluviation material }\end{array}$ & $\begin{array}{l}\text { Crystalline bedrock overlai } \\
\text { shallow layer of eluvium }\end{array}$ & \\
\hline
\end{tabular}

Fluvioglacial sediments, represented by wellgraded sand with gravel, cobbles and boulders, are found in the esker system of Lake Kamennoye. Their distribution is limited to relatively short (up to $5 \mathrm{~km}$ ) and low (up to $10 \mathrm{~m}$ ) esker ridges. The soil formation on fluvioglacial sediments occurs under well-drained regime, lack of moisture in the upper horizon, minor thickness of the soil profile, low organic matter accumulation in the illuvial horizon, minor biological activity.

Biogenic peat deposits have a complex, often isometric configuration, which well repeat the narrow depressions between blocks of the crystalline basement. In general, the central part of the Kostomuksha SNR is drier, with a more elevated and vertically dissected terrain. Wetlands are much more numerous in the north-western part of the Kostomuksha SNR and in the area of glaciolacustrine deposits. In the Kostomuksha SNR, biogenic peat deposits occur in small patches. Where moisture supply is excessive and solar energy supply to the ecosystem is insufficient, there are formed soils of the hydromorphic type. The acidic litter inhibits the microbiological activity, wherefore peat accumulates and a thicker coarse-humus forest floor is formed.

In the Kostomuksha SNR, the most uplifted basement blocks often outcrop or are barely covered with a thin layer of eluvium (mapped as bedrock outcrops). They are known in some parts of Lake Kamennoye shore, on the eastern shore of Lake Varnanema, and in the River Kamenka valley. Bedrock outcrops can be encountered amidst wetland terrain in the north-west part of the Kostomuksha SNR, as well as in its central part, in the sandy moraine area. Bedrock outcrops are the substrate for the formation of primitive soils (Leptosols). They contribute $<3 \%$ of the total soil pool, being shallow and rather poor. Thus, the structure and composition of the Quaternary deposits are directly dependent on the tectonicdenudation characteristics of the terrain, which influences the soil cover formation.

The soil formation has been influenced by the anthropogenic factor, too. We found that the soils retained features acquired during past hu- 
man activity in the forest (e.g. logging, swidden agriculture). Wildfires are a powerful factor for the morphological and physicochemical properties of soils. Wildfire impact leads to soil cover degradation as a result of bedrock exposure, and alter the species composition of the ground cover (Grigal \& McColl, 1977; Sharma, 1981; Köster et al., 2016). Thus, abundant coal occurrences in the soil profile indicate past wildfire events, and in some sites soil recovery takes a long time. Wildfire events generally broaden the spectrum of soil types, and changes in the structure of the soil cover are often associated with the pyrogenic history in the study area (Köster et al., 2016).

Analysis of the soil distribution shows that the leading soil-forming processes are litter formation, podzolisation, illuviation of organic matter and sesquioxides, peat deposition, and gleying. Soils with a podzolic horizon (E) in their morphological profile occupy the bulk of the studied Protected Area. Soils where the leading soil-forming process is peat deposition
(T horizon) have a limited distribution in depressions and on narrow river terraces. Soils formed on bedrock outcrops also occur in the Kostomuksha SNR.

In the Kostomuksha SNR, the most common soils are Illuvial-Humic Podzols and IlluvialFerric Podzols. Primitive soils over bedrock are also widespread. That is why they were chosen as the main study objects. Their morphological and physicochemical properties were analysed in detail.

The profile of Illuvial-Ferric Podzol soils has a thick dark brown forest floor (O), structureless dark grey podzolic horizon $(\mathrm{E})$, grey-brown illuvial horizon (BF). Hard mineralised inclusions are abundant in the mineral horizons. The profile description contains the macromorphological characteristics of the soils (Table 5, Fig. 2-1).

Illuvial-Humic Podzol is characterised by a loose, dark brown forest floor $(\mathrm{O})$, grey-while podzolic horizon $(\mathrm{E})$, bright dark yellow horizon (BHF), and abundant coal in the highest soil layers (Table 5, Fig. 2-2).

Table 5. Morphological properties of soils in the Protected Area

\begin{tabular}{|c|c|c|c|}
\hline Soil & Horizon & Depth, cm & Horizon description \\
\hline \multicolumn{4}{|c|}{ Profile exposed in a 200-year-old rupestrine cowberry pine stand, within the cowberry-lichen vegetation microgroup } \\
\hline \multirow{5}{*}{$\begin{array}{l}\text { Illuvial-Ferric } \\
\text { Podzol }\end{array}$} & $\mathrm{O}$ & $0-8$ & Forest floor, dark brown, moderately moist, structureless \\
\hline & $\mathrm{E}$ & $8-12$ & Podzolic horizon, dark grey, moderately moist, sandy, with coal \\
\hline & $\mathrm{BF}$ & $12-17$ & Illuvial horizon, yellowish-brown, moderately moist, sandy, Fe-Mn concretions, with coal \\
\hline & $\mathrm{BC}$ & $17-32$ & Light brown, moderately moist, sandy, dark-coloured organic matter accumulates at the contact with boulders \\
\hline & $\mathrm{C}$ & $32 \downarrow$ & Parent material, sandy, heavily bouldery \\
\hline \multicolumn{4}{|c|}{ Profile exposed in a 180-year-old rupestrine cowberry pine stand, within the bilberry-cowberry vegetation microgroup } \\
\hline \multirow{5}{*}{$\begin{array}{l}\text { Illuvial-Humic } \\
\text { Podzol }\end{array}$} & $\mathrm{O}$ & $0-9$ & Forest floor, dark-brown, moderately moist, loose, densely populated with plant roots \\
\hline & $\mathrm{E}$ & $9-14(17)$ & Dark grey, moderately moist, sandy, loose, with coal \\
\hline & BHF & $14(17)-26(30)$ & Illuvial horizon, dark yellow, turns darker downwards, moderately moist, sandy, Fe-Mn concretions, with coal \\
\hline & $\mathrm{BC}$ & $26(30)-33$ & Light brown, moderately moist, sandy, diffuse transition \\
\hline & $\mathrm{C}$ & $33 \downarrow$ & Parent material, heavily bouldery \\
\hline \multicolumn{4}{|c|}{ Profile exposed in a 110-year-old bilberry spruce stand, within the Sphagnum-cowberry vegetation microgroup } \\
\hline \multirow{5}{*}{$\begin{array}{l}\text { Peat Podbur (Histic } \\
\text { Entic Podzol) }\end{array}$} & TO & $0-11$ & $\begin{array}{l}\text { Light brown and dark brown, unevenly coloured, moist, plant remains retain identifiable anatomy, loose, } \\
\text { well-developed dwarf shrub root systems }\end{array}$ \\
\hline & $\mathrm{T}$ & $11-20$ & Dark brown, plant anatomy not recognizable, greasy, with coal \\
\hline & $\mathrm{Bg}$ & $20-26$ & Dark greyish-brown, wet, sandy, with coal, marble-coloured gleyed spots \\
\hline & $\mathrm{BCg}$ & $26-48$ & Dark greyish-yellow, wet, sandy, marble-coloured gleyed spots, quickly gets satiated \\
\hline & $\mathrm{Cg}$ & $48 \downarrow$ & Parent material, heavily bouldery, sandy \\
\hline \multicolumn{4}{|r|}{ Profile exposed in a 310-year-old rupestrine cowberry pine stand } \\
\hline \multirow{3}{*}{$\begin{array}{l}\text { Podzolised } \\
\text { Petrozem }\end{array}$} & $\mathrm{O}$ & $0-5$ & Forest floor, dark brown, moderately moist, structureless, loose, densely populated with plant roots \\
\hline & $\mathrm{Me}$ & $5-7$ & Dark grey, lighter towards the top due to podzolisation, moderately moist, sandy, with coal \\
\hline & $\mathrm{R}$ & $7 \downarrow$ & Bedrock \\
\hline \multicolumn{4}{|c|}{ Profile exposed in a 220-year-old bilberry spruce stand, within the cowberry-feathermoss microgroup } \\
\hline \multirow{3}{*}{ Typic Petrozem } & $\mathrm{O}$ & $0-8$ & Forest floor, brown, moist, densely populated with moss roots \\
\hline & $\mathrm{OM}$ & $8-10$ & brown, darker downwards, moist, with coal, organic matter accumulates at the contact with rock \\
\hline & $\mathrm{D}$ & $10 \downarrow$ & Rock \\
\hline
\end{tabular}




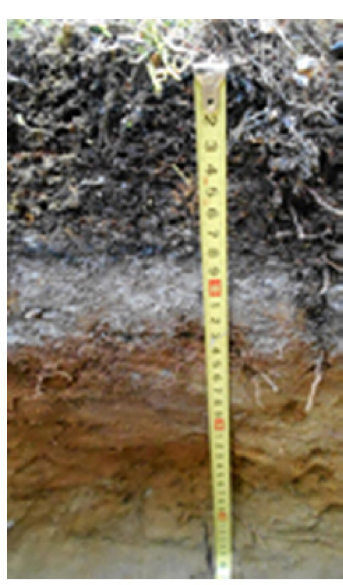

1

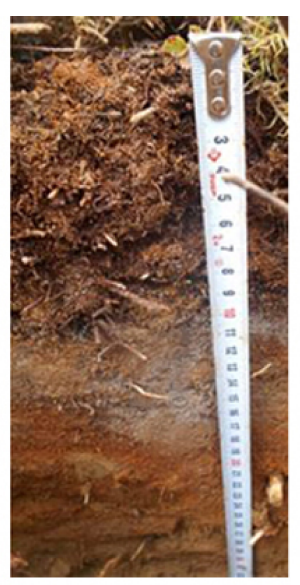

2

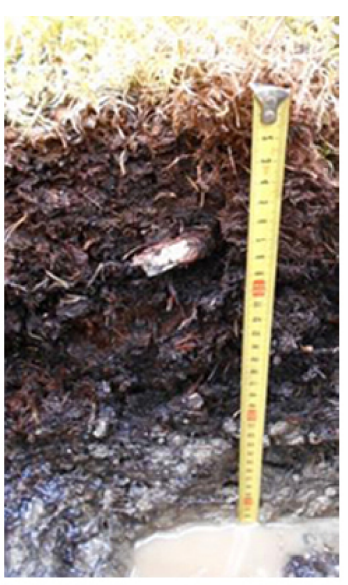

3

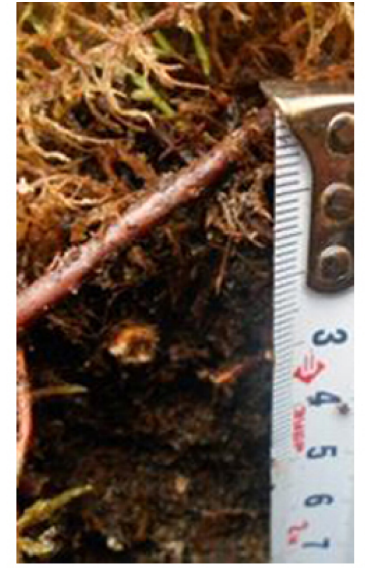

4

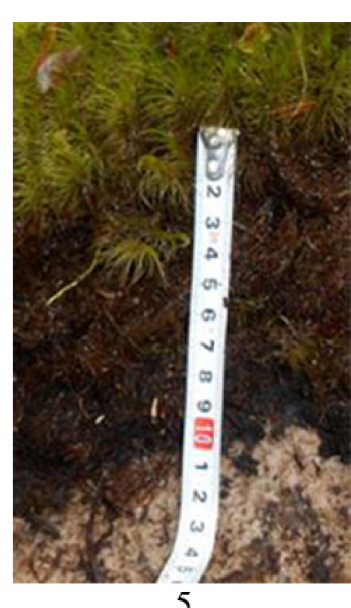

Fig. 2. Soils of the surveyed forest ecosystems in the Kostomuksha State Nature Reserve. Designations: 1 - Illuvial-Ferric Podzol; 2 - Illuvial-Humic Podzol; 3 - Peat Podbur; 4 - Podzolised Petrozem; 5 - Typic Petrozem.

The Peat Podbur features a thick top organic horizon (TO). The Bg horizon contains marble-coloured gleyed spots. Numerous FeMn smears and cutans are found all across the profile. The morphological structure is given in the profile description (Table 5, Fig. 2-3).

The profile of the Podzolised Petrozem features a thick forest floor $(\mathrm{O})$, a shallow podzolic horizon, and accumulation of dark brown organic matter at the contact with bedrock. The morphological structure is detailed in the soil profile description (Table 5, Fig. 2-4).

The Typic Petrozem is rather shallow. Its type is characterised by the dark brown upper horizon $(\mathrm{O})$ consisting of plant litter at different stages of decay, rusty-yellow spots in the mineral horizon, dark-coloured organic matter accumulating at the contact with rock (Table 5, Fig. 2-5).

The studied soils have been formed over parent material with similar or identical soil texture, namely sandy moraine with boulders (Table 6). In the parent rock material, the prevalent fraction is medium to coarse sand $(0.25$ $1.0 \mathrm{~mm}$ ), which accounts for $30.8-49.5 \%$.

The content of coarse silt $(0.01-0.05)$ is low, $1.36-6.3 \%$. The clay $(<0.001)$ content is $0.01-2.53 \%$, indicating a low degree of mineral weathering, and the youth of the soils (YlliHalla \& Mokma, 2002). In general, the soils are coarse-textured. This is typical for soils in this part of the Republic of Karelia. A distinctive feature of the soils is the formation of compact dark brown Fe-Mn grains. They can influence the redistribution of fine fractions and make the local increase in moisture of sites. A similar formation of compact miner- alised layers has been observed also in soils of other regions, with an optimal combination of hydrothermal conditions, organic matter availability, and a high iron content (Zaidelman \& Nikiforova, 2001; Vodyanitskiy, 2003; Charzynski et al., 2005; Gasparatos, 2007; Antsiferova, 2014; Bevandić et al., 2018).

The studied soils have an acid $\mathrm{pH}$ due to decaying litter of conifers, dwarf shrubs, and bryophytes (Table 7). The acidity is the highest in the top organic horizon (the forest floor), while it declines with depth.

The soils have a high hydrolytic activity, which is typical for soils in the Republic of Karelia (Morozova, 1991). The total carbon content is unevenly distributed across the soil profile, characterised by a biogenic accumulation pattern. Its content is the highest in the forest floor $(\mathrm{O})$ and declines sharply downwards. In the mineral layers, an eluviationilluviation pattern of carbon distribution is observed. This is typical for Podzols (Olsson, 2001; Olsson et al., 2009). The soils formed on sandy sediments over bedrock are characterised by the accumulation of organic matter in the lower part of the soil profile. This happens both through the migration from upper horizons and the in situ formation. The latter was indicated by a high carbon content in the $\mathrm{BC}$ horizon (up to $1 \%$ ). This is in agreement with the results of studies carried out in Northern Fennoscandia (Foster, 1988; Maslov \& Makarov, 2013). Presumably, in soils formed on bedrock microorganisms penetrate into cavities filled with organic matter. It is also possible that they form associations with plant root systems (Burke et al., 2002). 
Table 6. Soil texture of the forest soils in the Kostomuksha State Nature Reserve

\begin{tabular}{|c|c|c|c|c|c|c|c|}
\hline \multirow{2}{*}{ Horizon } & \multicolumn{7}{|c|}{ Grain size $(\mathrm{mm})$, percent shares of grain size fractions } \\
\hline & $1.0-0.5$ & $0.5-0.25$ & $0.25-0.05$ & $0.05-0.01$ & $0.01-0.005$ & $<0.001$ & $<0.01$ \\
\hline \multicolumn{8}{|c|}{ Illuvial-Ferric Podzol } \\
\hline $\mathrm{E}$ & 38.41 & 40.38 & 15.69 & 2.40 & 0.80 & 1.60 & 4.00 \\
\hline $\mathrm{BF}$ & 30.80 & 36.40 & 25.40 & 2.83 & 0.94 & 2.09 & 4.92 \\
\hline $\mathrm{BC}$ & 36.10 & 38.23 & 17.92 & 3.61 & 1.17 & 2.40 & 6.01 \\
\hline \multicolumn{8}{|c|}{ Illuvial-Humic Podzol } \\
\hline E & 49.50 & 31.20 & 12.00 & 2.80 & 3.20 & 2.80 & 5.60 \\
\hline BHF & 43.67 & 31.50 & 11.40 & 6.30 & 3.87 & 1.28 & 7.62 \\
\hline $\mathrm{BC}$ & 54.40 & 30.21 & 9.54 & 3.57 & 0.27 & 0.65 & 4.22 \\
\hline \multicolumn{8}{|c|}{ Peat-gley soil } \\
\hline $\mathrm{Bg}$ & 32.59 & 53.46 & 11.21 & 1.84 & 1.20 & 0.01 & 1.85 \\
\hline $\mathrm{Cg}$ & 31.20 & 51.30 & 14.52 & 1.89 & 0.03 & 0.72 & 2.61 \\
\hline \multicolumn{8}{|c|}{ Podzolised Petrozem } \\
\hline $\mathrm{Me}$ & 43.93 & 34.76 & 13.58 & 3.42 & 0.84 & 2.53 & 5.95 \\
\hline \multicolumn{8}{|c|}{ Typic Petrozem } \\
\hline B & 31.73 & 40.91 & 21.01 & 3.50 & 0.64 & 0.00 & 3.50 \\
\hline
\end{tabular}

Note: Soil horizons are designated in Table 5.

Table 7. Physicochemical properties of the soils in the Kostomuksha State Nature Reserve

\begin{tabular}{|c|c|c|c|c|c|c|c|c|c|}
\hline \multirow{2}{*}{ Soil horizon } & \multirow{2}{*}{ Thickness, cm } & \multirow{2}{*}{$\mathrm{pH}, \mathrm{H}_{2} \mathrm{O}$} & Нг & $\mathrm{S}$ & \multirow{2}{*}{$\mathrm{V}, \%$} & $\mathrm{C}$ & $\mathrm{N}$ & \multirow{2}{*}{$\mathrm{C} / \mathrm{N}$} & \multirow{2}{*}{ Ash content, LOI*, \% } \\
\hline & & & \multicolumn{2}{|c|}{ mg-eq./100 g } & & \multicolumn{2}{|c|}{$\%$} & & \\
\hline \multicolumn{10}{|c|}{ Illuvial-Ferric Podzol } \\
\hline $\mathrm{O}$ & $0-8$ & 3.85 & 21.40 & 127.30 & 85.60 & 37.67 & 0.95 & 39.30 & 5.80 \\
\hline $\mathrm{E}$ & $8-20$ & 4.73 & 1.20 & 2.70 & 69.20 & 0.08 & 0.05 & 16.10 & $2.10 *$ \\
\hline $\mathrm{BF}$ & $20-26(30)$ & 5.52 & 4.30 & 3.50 & 44.80 & 1.44 & 0.12 & 12.00 & 1.10 \\
\hline $\mathrm{BC}$ & $26(30)-42$ & 5.54 & 1.40 & 3.40 & 70.80 & 1.47 & 0.13 & 11.40 & 0.80 \\
\hline \multicolumn{10}{|c|}{ Illuvial-Humic Podzol } \\
\hline $\mathrm{O}$ & $0-9$ & 4.40 & 8.80 & 123.40 & 93.30 & 37.00 & 0.91 & 40.70 & 4.60 \\
\hline $\mathrm{E}$ & $9-14(17)$ & 5.10 & 50.90 & 4.90 & 8.70 & 1.32 & 0.04 & 40.10 & 1.10 \\
\hline $\mathrm{BHF}$ & $14(17)-26(30)$ & 5.20 & 5.10 & 4.40 & 46.30 & 5.50 & 0.12 & 45.10 & 1.60 \\
\hline $\mathrm{BC}$ & $26(30)-33$ & 5.60 & 4.80 & 4.10 & 46.10 & 0.34 & 0.01 & 34.00 & 1.10 \\
\hline \multicolumn{10}{|c|}{ Peat-gley soil } \\
\hline TO & $0-11$ & 5.15 & 28.48 & 100.65 & 77.90 & 44.02 & 1.09 & 40.30 & 7.29 \\
\hline Тп & $11-20$ & 5.51 & 24.40 & 136.76 & 84.90 & 42.48 & 0.89 & 47.40 & 10.40 \\
\hline $\mathrm{Bg}$ & $20-26$ & 5.76 & 3.14 & 96.06 & 96.80 & 1.34 & 0.09 & 13.50 & 1.90 \\
\hline $\mathrm{Cg}$ & $26-48$ & 5.79 & 0.00 & 2.25 & 36.60 & 2.33 & 0.05 & 40.9 & 0.40 \\
\hline \multicolumn{10}{|c|}{ Podzolised Petrozem } \\
\hline $\mathrm{O}$ & $0-5$ & 3.70 & 23.80 & 132.80 & 84.80 & 38.20 & 1.11 & 34.70 & 5.10 \\
\hline E & $5-7$ & 4.20 & 2.00 & 3.50 & 63.60 & 0.80 & 0.08 & 10.00 & 1.10 \\
\hline $\mathrm{Me}$ & $7-9$ & 4.60 & 1.20 & 4.90 & 80.30 & 1.20 & 0.11 & 10.90 & 1.60 \\
\hline \multicolumn{10}{|c|}{ Typic Petrozem } \\
\hline $\mathrm{O}$ & $0-5$ & 3.82 & 2.25 & 118.02 & 98.10 & 43.03 & 1.01 & 42.60 & 2.40 \\
\hline
\end{tabular}

Note: *LOI is the loss on ignition for mineral horizons. 
In the soils, the total nitrogen content is relatively low (within $0.05-1.11 \%$ ). Nitrogen content variations across the profile correlate with carbon content and show a biogenic accumulation pattern. In some cases, a nitrogen accumulation is seen also at the interface of the mineral body of the soil and bedrock.

The commonly recognised indicator of the activity of microbiological transformation of organic matter is the $\mathrm{C} / \mathrm{N}$ ratio. The high values of this indicator are related to the inhibited microbial-biochemical processes, low microorganism activity of the main ecotrophic groups, low enzymatic activity (catalase, urease, and protease). This is caused by the cold and humid climate, relatively low content of macro- and microelements in the parent rock materials, and a high soil acidity. Soils of the hydromorphic series have a broad $\mathrm{C} / \mathrm{N}$ ratio. This also demonstrates the unfavourable conditions for organic matter trans- formation. This is in agreement with data reported by Cédric et al. (2018).

Analysis of the total content of macro- and microelements in soils of the study area showed that a majority of the elements is accumulated in the top organic horizon $(\mathrm{O})$, while their content declines downwards the soil profile (Table 8). The eluviation-illuviation pattern of most of the element distribution across the podzolic soil profile portrays their genesis, that is in agreement with Fedorets et al. (2015). In some of the soil pits, the $\mathrm{Fe}, \mathrm{Zn}, \mathrm{Cu}$ content was above a clarke unit (Vinogradov, 1962). This reflects the characteristics of the Quaternary sediments, which in turn are characterised by a high diversity of minerals, and an elevated content of feldspar, muscovite and biotite in the coarse fraction (Lukashov \& Demidov, 2001). Noteworthy, geochemical rock characteristics of the study site adjacent to the ore deposit often have an abnormal content of ore-generated elements (Lavrov, 1979; Bölviken et al., 1990).

Table 8. Macro- and microelement content in the soils in the Kostomuksha State Nature Reserve

\begin{tabular}{|c|c|c|c|c|c|c|c|c|c|}
\hline \multirow{2}{*}{ Soil horizon } & $\mathrm{Ca}$ & $\mathrm{Mg}$ & $\mathrm{Fe}$ & $\mathrm{P}$ & K & S & $\mathrm{Zn}$ & $\mathrm{Pb}$ & $\mathrm{Cu}$ \\
\hline & \multicolumn{6}{|c|}{$\%$} & \multicolumn{3}{|c|}{$\mathrm{mg} / \mathrm{kg}$} \\
\hline \multicolumn{10}{|c|}{ Illuvial-Ferric Podzol } \\
\hline $\mathrm{O}$ & 0.81 & 0.06 & 0.02 & 0.10 & 0.08 & 0.07 & 102.80 & 2.40 & 16.80 \\
\hline $\mathrm{E}$ & 0.02 & 0.03 & 0.09 & 0.07 & 0.04 & 0.02 & 28.20 & - & 12.30 \\
\hline $\mathrm{BF}$ & 0.12 & 0.08 & 0.98 & 0.02 & 0.05 & 0.11 & 51.30 & - & 22.10 \\
\hline $\mathrm{BC}$ & 0.08 & 0.09 & 1.22 & 0.04 & 0.05 & 0.09 & 12.20 & - & 24.10 \\
\hline \multicolumn{10}{|c|}{ Illuvial-Humic Podzol } \\
\hline $\mathrm{O}$ & 0.14 & 0.05 & 0.040 & 0.08 & 0.06 & 0.03 & 63.10 & 4.20 & 11.00 \\
\hline $\mathrm{E}$ & 0.04 & 0.06 & 1.00 & 0.02 & 0.01 & 0.02 & 12.50 & - & 5.30 \\
\hline BHF & 0.05 & 0.20 & 0.60 & 0.06 & 0.04 & 0.12 & 36.00 & - & 16.10 \\
\hline $\mathrm{BC}$ & 0.05 & 0.11 & 4.20 & 0.02 & 0.05 & 0.08 & 18.00 & - & 8.00 \\
\hline \multicolumn{10}{|c|}{ Peat-gley soil } \\
\hline TO & 0.32 & 0.02 & 0.12 & 0.11 & 0.02 & 0.20 & 72.80 & 1.60 & 32.80 \\
\hline Тп & 0.28 & 0.01 & 0.18 & 0.21 & 0.04 & 0.18 & 28.60 & - & 20.20 \\
\hline $\mathrm{Bg}$ & 0.07 & 0.06 & 0.72 & 0.18 & 0.06 & 0.22 & 22.10 & - & 17.60 \\
\hline $\mathrm{Cg}$ & 0.02 & 0.07 & 2.23 & 0.06 & 0.05 & 0.06 & 11.20 & - & 8.80 \\
\hline \multicolumn{10}{|c|}{ Podzolised Petrozem } \\
\hline $\mathrm{O}$ & 0.72 & 0.04 & 0.16 & 0.12 & 0.11 & 0.05 & 72.10 & 3.80 & 12.20 \\
\hline $\mathrm{E}$ & 0.03 & 0.02 & 0.08 & 0.02 & 0.03 & 0.01 & 15.20 & - & 4.80 \\
\hline $\mathrm{Me}$ & 0.16 & 0.01 & 3.71 & 0.01 & 0.08 & 0.11 & 26.80 & - & 22.30 \\
\hline \multicolumn{10}{|c|}{ Typic Petrozem } \\
\hline $\mathrm{O}$ & 0.21 & 0.04 & 0.15 & 0.13 & 0.14 & 0.11 & 64.20 & 4.10 & 19.20 \\
\hline Clarke units & 1.37 & 0.63 & 3.00 & 0.09 & 1.36 & 0.85 & 50.00 & 10.00 & 20.00 \\
\hline
\end{tabular}


The acid reaction, coarse soil texture, and abundant precipitation are the factors promoting the vertical migration of macro- and microelements in the top soil layers (Berthelsen et al., 1994). The biotic ecosystem component, performing the cycling of plant mineral nutrients, plays a major role in the chemical element accumulation for its structural and energy purposes (Vanhala et al., 1998; Sedia \& Ehrenfeld, 2006; Buscot \& Varma, 2009; Dobrovolskaya et al., 2015). In shallow primitive soils, the role of plant root systems is especially high for the redistribution of mineral elements. Perhaps, under unfavourable edaphic conditions, microorganisms actively influence the growth of roots, thus shaping plant root architecture (Ortíz-Castro et al., 2009). Although in our sites these soils occur as local patches, they support the "soil continuum» necessary in the forest community to function under the given environmental and climatic conditions (Medvedeva et al., 2018).

\section{Conclusions}

The conducted study demonstrated that in the soil cover, zonal Al-Fe-humus soils (Podzols) predominate, while shallow soils (Leptosols) also occur throughout the Kostomuksha SNR area, despite occupying a limited area. Intrazonal peat moor soils (Histosols) are being formed in topographic lowlands. In relation to the forest stand composition, the soil distribution shows that Illuvial-Ferric (Albic Rustic) Podzols formed under pine forests are the most widespread soils. According to our estimation, the most common soils have an average value of $<60$ scores, which is typical for low-productivity forest stands. The soil texture patterns and physicochemical properties of most common soils were studied in the Kostomuksha SNR. Morphologically, the soils usually feature a shallow profile and a thick forest floor $(\mathrm{O})$, while the thickness of the podzolic horizon varies widely. The soil texture depends on the parent rock materials. In the study area, soils are mostly coarse-textured. The low content of clay $(<0.001)$ fraction indicates both a low level of mineral weathering minor and young soils. The soils have a relatively low nitrogen content and high carbon content. This indicates a slowness of the biological transformation of organic matter. In the soils, the content of the majority of macro- and microelements is quite low, which is generally typical for soils in the Republic of Karelia. The exceptions are $\mathrm{Fe}, \mathrm{Cu}, \mathrm{Zn}$, concen- trations which are higher than clarke units due to the vicinity of crustal iron-ore occurrences.

\section{Acknowledgements}

The authors are grateful to the staff of the Kostomuksha State Nature Reserve and its director Sergey V. Tarkhov for helping during fieldwork, as well as to colleagues from the Finnish Environment Institute for collaboration during fieldwork. The studies were financed by the federal budget through state order to KarRC RAS (Forest Research Institute KarRC RAS, Institute of Geology KarRC RAS) and supported by funding from the Kostomuksha State Nature Reserve (contracts №1/016; 2/017; 3/017; 1/018; 2/018).

\section{References}

Antsiferova O.A. 2014. Ferromanganese nodule neoformations in the soils of the western part of the Kaliningrad region. IKBFU's Vestnik 1: 73-78. [In Russian]

Aparin B.F., Kasatkina G.A., Matinian N.N., Sukhacheva E.U. 2007. Red Data Soil Book of the Leningrad region. Saint Petersburg: Aeroplan. 320 p. [In Russian]

Arnalds O., Hallmark C.T., Wilding L.P. 1995. Andisols from four different regions of Iceland. Soil Science Society of America Journal 59(1): 161-169. DOI: 10.2136/sssaj1995.03615995005900010025x

Berthelsen B.O., Årdal L., Steinnes E., Abrahamsen G., Stuanes A.O. 1994. Mobility of heavy metals in pine forest soils as influenced by experimental acidification. Water, Air and Soil Pollution 73(1): 29-48. DOI: 10.1007/BF00477974

Bevandić S., Brenko T., Babajić E., Borojević Šoštarić S. 2018. Formation mechanisms of Fe-Mn concretions in the Vijenac Quarry, Dinaric Ophiolite Zone. Mining-Geology-Petroleum Engineering Bulletin 33(3): 63-74. DOI: 10.17794/rgn.2018.3.7

Bölviken B., Kullerud G., Loucks R. 1990. Geochemical and metallogenic provinces: a discussion initiated by results from geochemical mapping across Northern Fennoscandia. Journal of Geochemical Exploration 39(1-2): 49-90. DOI: 10.1016/03756742(90)90069-M

Burke D.J., Hamerlynck E.P., Dittmar H. 2002. Interactions among plant species and microorganisms in salt marsh sediments. Applied and Environmental Microbiology 68(3): 1157-1164. DOI: 10.1128/ AEM.68.3.1157-1164.2002

Buscot F., Varma A. 2009. Microorganisms in Soils: Roles in Genesis and Functions. Springer Science \& Business Media. 422 p.

Cédric B., Müller M., Schulin R., Leifeld J. 2018. Peat decomposability in managed organic soils in relation to land use, organic matter composition and temperature. Biogeosciences 15(3): 703-719. DOI: 10.5194/ bg-15-703-2018

Charzynski P., Hulisz P., Bednarek R. 2005. Diagnostic subsurface horizons in systematics of polish soils and 
their analogues in WRB classification. Eurasian Soil Science 38(Suppl.1): 55-59.

Dazzi C., Lo Papa G. 2015. Anthropogenic soils: general aspects and features. Ecocycles 1(1): 3-8. DOI: 10.19040/ecocycles.v1i1.23

Deguignet M., Juffe-Bignoli D., Harrison J., MacSharry B., Burgess N., Kingston N. 2014. United Nations List of Protected Areas. UNEP-WCMC: Cambridge. UK. 30 p.

Dmitriev E.A. 1995. Mathematical Statistics in Soil Science. Moscow: MSU. 291 p. [In Russian]

Dobrovolskaya T.G., Zvyagintsev D.G., Chernov I.Yu., Golovchenko A.V., Zenova G.M., Lysak L.V., Manucharova N.A., Marfenina O.E., Polyanskaya L.M., Stepanov A.L., Umarov M.M. 2015. The Role of Microorganisms in the Ecological Functions of Soils. Eurasian Soil Science 48(9): 959-967. DOI: 10.1134/S1064229315090033

Dobrovolskiy G.V. (Ed.). 1997. Soil, city, environment. Moscow: Foundation for Economic Literacy. 320 p. [In Russian]

Elina G.A., Lykashov A.D., Tokarev P.N. 2005. Mapping of vegetation and landscapes on temporary sections of the Holocene of the taiga zone of eastern Fennoscandia. Saint Petersburg: Nauka. 112 p. [In Russian]

Erokhin S., Moskvitin E. (Eds.). 2001. Republic of Karelia: Atlas. Saint Petersburg. 136 p. [In Russian]

Erukov G.V., Morozova R.M., Lazareva I.P. 1977. Forest soils and soil cover of the green zone of Kostomukshi. In: G.S. Biske, I.M. Nesterenko, O.I. Potapova (Eds.): Biological resources of the Kostomuksha region, ways of development and protection. Petrozavodsk: Karelian Branch of AS USSR. P. 59-78. [In Russian]

Fedorets N.G., Bakhmet O.N., Medvedeva M.V., Akhmetova G.V., Novikov S.G., Tkachenko Yu.N., Solodovnikov A.N. 2015. Heavy metals in the soils of Karelia. Petrozavodsk: Karelian Research Centre of RAS. 222 p. [In Russian]

Fedorets N.G., Morozova R.M., Sinkevich S.M., Zaguralskaya L.M. 2000. Evaluation of productivity of forest soils in Karelia. Petrozavodsk: Karelian Research Centre of RAS. 195 p. [In Russian]

Field determinant of Russian soils. Moscow: Dokuchaev Soil Science Institute, 2008. 150 p. [In Russian]

Foster R.C. 1988. Microenvironments of soil microorganisms. Biology and Fertility of Soils 6(3): 189-203. DOI: $10.1007 / \mathrm{BF} 00260816$

Gasparatos D. 2007. Genesis of Fe-Mn Concretions and Nodules in Alfisols of Thessaly. PhD Thesis. Athens: Agricultural University of Athens. 275 p.

Getzner M., Vik M.L., Brendehaug E., Lane B. 2014. Governance and management strategies in national parks: implications for sustainable regional development. International Journal of Sustainable Society 6(1-2): 82-101. DOI: 10.1504/IJSSOC.2014.057891

Grigal D.F., McColl J.G. 1977. Litter decomposition following forest fire in Northeastern Minnesota. Journal of Applied Ecology 14(2): 531-538. DOI: $10.2307 / 2402565$
Gromtsev A.N. (Ed.). 2020. State report on the environment of the Republic of Karelia in 2019. Petrozavodsk: Ministry of Nature Management and Ecology of the Republic of Karelia. 248 p. [In Russian]

Gromtsev A.N. 2000. Landscape ecology of taiga forests: theoretical and applied aspects. Petrozavodsk: Karelian Research Centre of RAS. 144 p. [In Russian]

Hiederer R., Michéli E., Durrant T. 2011. Evaluation of BioSoil Demonstration Project - Soil Data Analysis. Luxembourg: Publications Office of the European Union. $155 \mathrm{p}$.

IUSS Working Group WRB. 2015. World Reference Base for Soil Resources 2014, update 2015. International soil classification system for naming soils and creating legends for soil maps. World Soil Resources Reports №106. Rome: FAO. 192 p.

Kolomytsev V.A., Shiltsova V.G. (Eds.). 1998. Integrated environmental monitoring in the Republic of Karelia. Petrozavodsk: Karelian Research Centre of RAS. 115 p. [In Russian]

Köster K., Köster E., Orumaa A., Parro K., Jõgiste K., Berninger F., Pumpanen J., Metslaid M. 2016. How Time since Forest Fire Affects Stand Structure, Soil Physical-Chemical Properties and Soil $\mathrm{CO}_{2}$ Efflux in Hemiboreal Scots Pine Forest Fire Chronosequence? Forests 7(9): 201. DOI: 10.3390/f7090201

Kulmatiski A., Sprouse S., Beard K. 2017. Soil type more than precipitation determines fine-root abundance in savannas of Kruger National Park, South Africa. Plant and Soil 417(1-2): 523-533. DOI: 10.1007/ s11104-017-3277-y

Lavrov M.M. 1979. Hyperbasites and stratification of peridotite-gabbro-norite intrusions of the Precambrian of Northern Karelia. Leningrad: Nauka. 136 p. [In Russian]

Lordkipanidze M., Boer C., Bressers H. 2015. Assessing governance context to increase drought resilience: The case of the Drents-Friese Wold National Park. International Journal of Water Governance 4: 69-92.

Lu X., Zhang X. 2008. ${ }^{226} \mathrm{Ra},{ }^{232} \mathrm{Th}$ and ${ }^{40} \mathrm{~K}$ activities in soils of Cuihua Mountain National Geological Park, China. Environmental Geology 56(2): 353-357. DOI: 10.1007/s00254-007-1170-3

Lukashov A.D., Demidov I.N. 2001. Conditions for the formation of relief and Quaternary deposits of Karelia in the late and post-glacial periods as the basis for the formation of the modern natural environment. Transactions of KarRC RAS. Biogeography 2: 30-47. [In Russian]

Martinelli N., Pignatelli O. 1995. Dendroecological Investigations at the permanent plots IT01-IT02 in South Tyrol. Wald und Natur. Integrated Monitoring Programme. Available from http://www. provinz.bz.it/land-forstwirtschaft/wald-holz-almen/ interaktive-karte.asp?publ_action $=300 \&$ publ_image_id $=471177$

Maslov M.N., Makarov M.I. 2013. Organic matter of the soil of the mountain tundra in North Fennoscandia. Moscow University Soil Science Bulletin 68(3): 99-103. 
Medvedeva M.V., Akhmetova G.V., Fedorets N.G., Yakovlev A.S., Raevsky B.V., Travin V.V. 2018. Soils of Low-Mountain Landscapes of North Karelia. Eurasian Soil Science 51(2): 131-139. DOI: 10.1134/ S1064229318020096

Medvedeva M.V., Bakhmet O.N., Yakovlev A.S. 2003. Biological diagnostics of aerotechnogenic pollution in forest soils of Eastern Fennoscandia. Eurasian Soil Science 36(1): 101-106.

Medvedeva M.V., Bakhmet O.N., Yakovlev A.S. 2006a. Microbiological and biochemical indicators of the state of Karelian soils exposed to aerotechnogenic pollution. Eurasian Soil Science 39(1): 62-66. DOI: 10.1134/S106422930601008X

Medvedeva M.V., Bakhmet O.N., Yakovlev A.S. 2006 b. Decomposition of spruce falloff under condition of air-borne industial pollution. Lesovedenie 4: 75-77. [In Russian]

Medvedeva M.V., Yakovlev A.S. 2011. Changes in the biochemical characteristics of soils in the impact zone of the Kostomuksha ore-dressing enterprise. Eurasian Soil Science 44(2): 211-216. DOI: 10.1134/S1064229311020086

Medvedeva M.V., Bakhmet O.N. 2001. The current state of microbiocenosis of forest soils contaminated with airpollutants in the North-West of Russia. Lesovedenie 6: 37-40. [In Russian]

Melillo J.M., Lu X., Kicklighter D.W., Reilly J.M., Cai Y., Sokolov A.P. 2016. Protected areas' role in climatechange mitigation. Ambio 45(2): 133-145. DOI: 10.1007/s13280-015-0693-1

Mikhailovskaya O.N. 1951. On natural and cultivated soils...: (from materials of the soil map of the KASSR). Izvestiya of the Karelian-Finnish branch of the USSR Academy of Sciences 3: 13-32. [In Russian]

Morozova R.M. (Ed.). 1996. Soil map of Karelia. Scale: 1:1 000 000. Archive of the Laboratory for Forest Pedology of the FRI KarRC RAS. [In Russian]

Morozova R.M. 1991. Forest soils of Karelia. Leningrad: Nauka. 184 p. [In Russian]

Olsson M. 2001. Soil Survey in Sweden. European soil bureau research report №6. P. 151-145.

Olsson M.T., Erlandsson M., Lundin L., Nilsson T., Nilsson Å., Stendahl J. 2009. Organic carbon stocks in Swedish Podzol soils in relation to soil hydrology and other site characteristics. Silva Fennica 43(2): 209222. DOI: $10.14214 /$ sf.207

Ortíz-Castro R., Contreras-Cornejo H.A., Macías-Rodríguez L., López-Bucio J. 2009. The role of microbial signals in plant growth and development. Plant Signaling and Behavior 4(8): 701-712. DOI: 10.4161/psb.4.8.9047

Peikhvasser V.N. (Ed.). 1989. Atlas of the Karelian ASSR (Maps). Moscow: GUGK. 40 p. [In Russian]

Poikolainen J. 1995. The effects of the emissions of the Kostomuksha mining complex on the chemical com- position of deposition and soil water in the surrounding pine forests. Water Air and Soil Pollution 85(3): 1689-1694. DOI: 10.1007/BF00477223

Raevsky B.V. 2016. Structural features of the forest area of the Kostomuksha State Nature Reserve. In: Scientific research in nature reserves and national parks of Russia. Petrozavodsk. P. 186. [In Russian]

Rodríguez N., Notario J., Arbelo C.D., Rodríguez-Rodríguez A., Guerra J.A. 2014. Spatial variability of soil properties and soils classification in Teide National Park (Tenerife, Canary Islands). In: D. Arrouays, N. McKenzie, J. Hempel, A. Richer de Forges, A.B. McBratney (Eds.): GlobalSoilMap. Basis of the Global Spatial Soil Information System. London: Taylor \& Francis. P. 191-196.

Sedia E.G., Ehrenfeld J.G. 2006. Differential effects of lichens and mosses on soil enzyme activity and litter decomposition. Biology and Fertility of Soils 43(2): 177-189. DOI: 10.1007/s00374-006-0077-6

Sharma G.D. 1981. Effect of fire on soil microorganisms in a Meghalaya pine forest. Folia Microbiologica 26(4): 321-327. DOI: 10.1007/BF02927260

Shishov L.L., Tonkonogov V.D., Lebedeva I.I., Gerasimova M.I. 2004. Classification and diagnostics of Russian soils. Smolensk: Oikumena. 342 p. [In Russian]

UNEP-WCMC and IUCN. 2016. Protected Planet Report 2016. Cambridge UK; Gland, Switzerland: UNEPWCMC and IUCN. 74 p.

Van Herk C., Mathijssen-Spiekman E., De Zwart D. 2003. Long distance nitrogen air pollution effects on lichens in Europe. The Lichenologist 35(4): 347-359. DOI: 10.1016/S0024-2829(03)00036-7

Van Wensem J., Amorim M., Römbke J. 2008. Soil protection in Europe. Integrated Environmental Assessment and Management 4(4): 519-520. DOI: 10.1897/ IEAM_2008-060d.1

Vanhala P., Kapanen A., Fritze H., Niemi R.M. 1998. Microbial activity and biomass in four Finnish coniferous forest soils - spatial variability and effects of heavy metals. Boreal Environment Research 3(3): 287-295.

Vinogradov A.P. 1962. Average content of elements in the earth's crust. Geokhimia 7: 555-557. [In Russian]

Vodyanitskiy Yu.N. 2003. Chemistry and mineralogy of soil iron. Moscow: Dokuchaev Soil Science Institute. 238 p. [In Russian]

Vorobyeva L.A. 1998. Chemical analysis of soils. Moscow: Moscow State University. 272 p. [In Russian]

Ylli-Halla M., Mokma D. 2002. Problems encountered when classifying the soils of Finland. European soil bureau research report №7. P. 183-189.

Zaidelman F.R., Nikiforova A.S. 2001. Genesis and diagnostic significance of neoformations in soils of the forest and forest-steppe zones. Moscow: MSU. 216 p. [In Russian] 


\title{
ОСОБЕННОСТИ ПОЧВ И ПОЧВЕННОГО ПОКРОВА ЗАПОВЕДНИКА «КОСТОМУКШСКИЙ» (РОССИЯ)
}

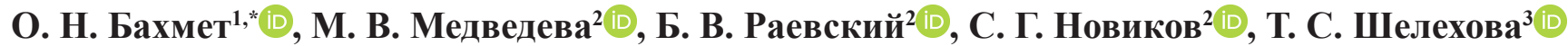 \\ ${ }^{1}$ Отдел комплексных исследований Карельского научного ичентра РАН, Россия \\ *e-mail: obahmet@mail.ru \\ ${ }^{2}$ Институт леса Карельского научного ичентра РАН, Россия \\ ${ }^{3}$ Институт геологии Карельского научного иеентра РАН, Россия
}

Исследования проведены на территории заповедника «Костомукшский», расположенного в северной тайге Восточной Фенноскандии. Рассмотрены основные этапы изучения почв и почвенного покрова в данном районе. Проведен комплексный анализ почв и почвенного покрова ООПТ в контексте исследования почвообразующих пород, древесной растительности. Почвы ненарушенных территорий являются эталоном при мониторинге антропогенно-нарушенных лесных экосистем, что делает актуальным проведение данных работ. Целью исследования является изучение состава почвенного фонда, а также свойств почв, наиболее распространенных на территории Костомукшского заповедника. Изучены морфологические и физико-химические свойства почв. Природноклиматические условия заповедника благоприятствуют развитию подзолообразовательного процесса. Установлено, что наибольшее распространение на ООПТ имеют зональные альфегумусовые почвы (Podzols). На выходах коренных пород формируются маломощные почвы (Leptosols), oни занимают небольшую долю в почвенном фонде, продуктивность произрастающих на них растений низкая. В условиях повышенного увлажнения формируются интразональные торфяные болотные почвы (Histosols). Они занимают небольшие площади и развиваются в понижениях рельефа, между холмами, по окраинам болот, в блюдцеобразных впадинках скальных обнажений. Определено таксономическое положение исследованных почв в соответствии с региональной классификацией и международной классификацией WRB. Установлена приуроченность почв к древостоям различного породного состава. Подзолы иллювиально-железистые (Albic Rustic Podzols) господствуют под сосняками (Pinus sylvestris), ельники (Picea abies) уступают им по площади распространения на ООПТ. Березняки (Betula pendula), сформировавшиеся на почвах альфе-гумусового генезиса, не занимают большие площади. Они встречаются на вырубках, почвенно-ветровальных комплекcax, в местах, пройденных пожарами. Проведен анализ приуроченности почв к четвертичным отложениям. Коренные горные породы перекрываются четвертичными песчаными и супесчаными отложениями, мощность которых изменяются в широком диапазоне (от 5 см до 5 м). Широко распространенными являются моренные и ледниково-озерные отложения, торфяные отложения распространены на территории исследования в меньшей степени. Для морфологического строения исследованных почв характерен хорошо дифференцированный профиль, мощная лесная подстилка $(\mathrm{O})$, наличие подзолообразовательного процесса. В основном, распространены почвы легкого гранулометрического состава. Низкое содержание мелкодисперсных фракций свидетельствует о невысоком выветривании первичных минералов в почвенной толще в условиях холодного гумидного климата, четкой зависимости в их распределении по профилю почв не обнаружено. Изученные почвы - кислые. Наибольшей кислотностью в профиле почв отличается лесная подстилка. По мере продвижения вглубь почвенной толщи кислотность снижается. Специфика первичных факторов почвообразования сказывается на формировании органического вещества почв. Почвы характеризуются высоким содержанием углерода $(\mathrm{C})$ в верхнем органогенном горизонте, с глубиной его содержание резко снижается. Распределение азота (N) по профилю почв связано с распределением органического вещества в целом: наибольшее в лесной подстилке, в минеральной толще оно снижается. Широкое отношение $\mathrm{C}: \mathrm{N}$ в лесной подстилке косвенно свидетельствует о заторможенности процессов микробной трансформации органического вещества в почвах. Для почв ООПТ, также как и в целом для Карелии, характерно невысокое содержание большинства макро- и микроэлементов. Исключение составляют $\mathrm{Fe}, \mathrm{Cu}, \mathrm{Zn}$, что обусловлено приуроченностью территории исследования к железорудным проявлениям в земной коре. Почвенный покров данной ООПТ отличается значительной пестротой, что связано с частой сменой почвообразующих пород и рельефом местности. В связи с тем, что почвы имеют легкий гранулометрический состав, низкое содержание гумуса, промывной водный режим, возможно, вымывание элементов за пределы корнеобитаемой зоны. Полученные данные могут быть основой при проведении мониторинга природной среды, корректно экстраполированы на почвы ненарушенных лесных экосистем Фенноскандии.

Ключевые слова: бонитировочная оценка почв, Восточная Фенноскандия, лесные почвы, лесные экосистемы, четвертичные отложения 